\title{
Temporal variability of ammonia emission potentials for six plant species in an evergreen subtropical forest in southwest China
}

\author{
Juan Cui ${ }^{1,2}$ - Zhangwei Wang ${ }^{1,2} \cdot$ Xiaoshan Zhang ${ }^{1,2}$ • Jan Mulder ${ }^{3}$. \\ Meigen Zhang ${ }^{4}$
}

Received: 16 March 2016 / Accepted: 16 February 2017 /Published online: 13 March 2017

(C) Springer-Verlag Berlin Heidelberg 2017

\begin{abstract}
The temporal variability of leaf ammonia $\left(\mathrm{NH}_{3}\right)$ emission potentials (the ratio of leaf tissue ammonium to proton concentration) and nitrogen $(\mathrm{N})$ pools of six dominant plant species were investigated at the Tieshanping (TSP) forested catchment, southwest China. The results showed that the $\mathrm{NH}_{3}$ emission potentials and $\mathrm{N}$ pools presented small variations among seasons, which were mainly controlled by plant species and the leaf age. Also, high emission potential in one species did not correspond to high tissue $\mathrm{N}$ content. Specifically, the Chinese fir (Cunninghamia lanceolata) had higher $\mathrm{NH}_{3}$ emission potential (mean: 46.2) but lower $\mathrm{N}$ content (mean: $1.6 \%$ of Dw). The leaf privet (Ligustrum quihoui Carr.) was with the moderate emission potential (15) and the highest $\mathrm{N}$ content $(2.7 \%$ of Dw) on average, which for the Masson pine (Pinus massoniana) were both low. Overall, the emission potentials of the six species were too low $(<200)$ to build up a sufficiently high $\mathrm{NH}_{3}$ partial pressure in the leaves. Therefore, the Masson pine dominant subtropical
\end{abstract}

Responsible editor: Hailong Wang

Electronic supplementary material The online version of this article (doi:10.1007/s11356-017-8650-0) contains supplementary material, which is available to authorized users.

Zhangwei Wang

wangzhw@rcees.ac.cn

1 Research Center for Eco-Environmental Sciences, Chinese Academy of Sciences, Beijing 100085, China

2 University of Chinese Academy of Sciences, Beijing 100049, China

3 Department of Environmental Sciences, Norwegian University of Life Sciences, Postbox 5003, Ås 1430, Norway

4 State Key Laboratory of Atmospheric Boundary Layer Physics and Atmospheric Chemistry, Institute of Atmospheric Physics, Chinese Academy of Sciences, Beijing 100029, China forest at TSP acts as a sink for the atmospheric $\mathrm{NH}_{3}$, indicating that using the $\mathrm{N}$ flux in throughfall only may significantly underestimate the $\mathrm{N}$ income of the ecosystem. The results are informative for future modeling of plant-atmosphere $\mathrm{NH}_{3}$ exchange and estimating $\mathrm{N}$ budget in local or regional scales.

Keywords Ammonia $\cdot$ Emission potential $\cdot$ Temporal variability $\cdot$ Nitrogen pool $\cdot$ Subtropical forests

\section{Introduction}

Forest canopies and forest ecosystems are considered to be nitrogen $(\mathrm{N})$ limitation and not $\mathrm{N}$ excess in pre-industrial times (Rennenberg et al. 1998). However, due to the increase use of fossil fuels and expansion in agriculture, many forests in China are exposed to excessive amounts of $\mathrm{N}$ (Chen and Mulder 2007). Ammonia $\left(\mathrm{NH}_{3}\right)$ accounts for almost half of the reactive $\mathrm{N}$ pollutants in the atmosphere with wide ecological and environmental impacts, including eutrophication, acidification, alteration of biodiversity, and global warming (Allen et al. 2011; Beusen et al. 2008; Krupa 2003; Stamenkovic et al. 2015; Sutton et al. 2008; Wang and Schjoerring 2012). In China, the total $\mathrm{NH}_{3}$ emission was estimated to be $13.6 \mathrm{Tg}$ in $2000,50 \%$ of which came from fertilizer applications and $38 \%$ from other agricultural sources. In recent years, different values of $\mathrm{NH}_{3}$ emission estimation have been reported with some uncertainties, e.g., $16.1 \mathrm{Tg}$ by Dong et al. (2010) and $9.8 \mathrm{Tg}$ by Huang et al. (2012) in 2006.

Forest vegetation often acts as a sink for the atmospheric $\mathrm{NH}_{3}$ (Hansen et al. 2013; Neirynck et al. 2005). However, owing to the existence of stomatal $\mathrm{NH}_{3}$ compensation point $\left(\chi_{\mathrm{s}}\right)$ in plant leaves, the exchange between the atmosphere and the canopies is in fact bi-directional (Flechard et al. 2013). Episodes of $\mathrm{NH}_{3}$ emission may occur when the air concentration of $\mathrm{NH}_{3}$ goes 
below the $\chi_{\mathrm{s}}$ (Geßler et al. 2000; Neirynck and Ceulemans 2008; Zhang et al. 2010). Canopies exposed to high atmogenic $\mathrm{N}$ deposition are more likely to emit $\mathrm{NH}_{3}$ (Wang et al. 2013).

In the absence of $\chi_{\mathrm{s}}$, the ratio between ammonium $\left(\mathrm{NH}_{4}{ }^{+}\right)$and proton $\left(\mathrm{H}^{+}\right)$concentration of leaf extracts is calculated to represent the potential $\mathrm{NH}_{3}$ emission designated $\Gamma$, although the parameter is not a directmeasure of the $\mathrm{NH}_{3}$ exchange between plants and the atmosphere (David et al. 2009; Mattsson and Schjoerring 2002; Mattsson et al. 2009). $\Gamma$ is temperature independent and dimensionless, and therefore often more convenient to use than $\chi_{\mathrm{s}}$ (Nemitz et al. 2000a, b). Clear seasonal variations of $\Gamma$ for a beech forest, with peak values at autumn, have been found by Wang et al. (2011) in Demark. The $\Gamma$ value alters across plant species such as in managed grasslands (Mattsson et al. 2009) and in forests (Wang etal.2013). Within the canopy, different tissues (related to different growing stages) of the plant contribute differently to $\mathrm{NH}_{3}$ flux potentials (Herrmann et al. 2009). The senescent and fallen leaves are recognized as the strongest source, whereas green leaves may recapture $\mathrm{NH}_{3}$ emitted in deeper layers of the canopy (David et al. 2009; Wang and Schjoerring 2012).

For the high applications of $\mathrm{N}$ fertilizer, the $\Gamma$ values of grass or crops have drawn much attention (David et al. 2009; Mattsson and Schjoerring 1996; Mattsson et al. 2009; Nemitz et al. 2000a; van Hove et al. 2002). In contrast, only sporadic works were conducted in temperate forest areas with a narrow range of plant species (Neirynck and Ceulemans 2008; Wang et al. 2011; 2013). Limited information is available on $\Gamma$ values and $\mathrm{N}$ pools of plants in subtropical forests. To the best of our knowledge, parameterization of bidirectional $\mathrm{NH}_{3}$ exchange between forests and the atmosphere is mainly based on datasets from temperate locations in northern Europe, and there exists large uncertainties when applied to tropical and subtropical areas (Massad et al. 2010).

Therefore, the primary objectives of this work are (1) to investigate the seasonal variations of $\mathrm{NH}_{3}$ emission potentials and $\mathrm{N}$ pools for six dominant plant species at the Tieshanping forested catchment, southwest China; (2) to assess the effect of different leaf ages on the $\mathrm{NH}_{3}$ emission potentials and $\mathrm{N}$ pools within the canopies; and (3) to identify the subtropical forest in this catchment acting as a sink or source for the atmospheric $\mathrm{NH}_{3}$ preliminarily. These will be quite valuable for modeling the plant-atmosphere $\mathrm{NH}_{3}$ exchange and estimating $\mathrm{N}$ budget in local and regional scales, as well as assessing the ecological and environmental functions of subtropical forests on the reactive $\mathrm{N}$ pollutants.

\section{Material and method}

\section{Site description}

Tieshanping (TSP) $\left(29^{\circ} 38^{\prime} \mathrm{N}, 106^{\circ} 41^{\prime} \mathrm{E}\right)$ is a 16.3 -ha forested catchment, located about $25 \mathrm{~km}$ northeast of Chongqing, southwest China. It is typically subtropical monsoonal climate with a mean annual temperature of $18.2^{\circ} \mathrm{C}$, and the total annual rainfall is $1028 \mathrm{~mm}$ (3-year averages, 2001-2003). The inorganic $\mathrm{N}$ deposition was $41 \mathrm{~kg} \mathrm{~N}^{-1}$ year $^{-1}, 61 \%$ of which occurred in the form of ammonium $\left(\mathrm{NH}_{4}{ }^{+}-\mathrm{N}\right)$ (Chen and Mulder 2007). The soil type is a clay-rich loamy yellow mountain soil classified as Haplic Acrisol (WRB 2006) developed from sandstone. The catchment is an evergreen coniferous-broad-leaved mixed forest planted since the 1960s, dominated by Masson Pine (Pinus massoniana) and some associated species such as Chinese fir (Cunninghamia lanceolata), Camphor (Cinnamomum camphora), and Schima (Schima superba Gardn. et Champ). Below the tall arbor trees, well-developed understory of evergreen shrubs exist (Chen and Mulder 2007; Zhu et al. 2013). The average forest stand stocking in 2002 was about 1095 trees ha ${ }^{-1}$, and the average height and mean diameter at breast height of Masson pine (Kraft class 1-3) were $15.5 \mathrm{~m}$ and $193 \mathrm{~mm}$, respectively (Jiang and Zhang 2008; Wang et al. 2007).

The atmospheric concentration of $\mathrm{NH}_{3}$ was measured with denuders in the forest according to Lun et al. (2003) and Nie et al. (2010). The seasonal mean air concentrations of $\mathrm{NH}_{3}$ were $2.56,2.89,1.45$, and $1.91 \mathrm{nmol} \mathrm{mol}^{-1}$ in spring, summer, autumn, and winter, respectively.

\section{Sample collection}

In this study, six dominant plant species from the arbor layers to the understory were investigated, i.e., the Masson pine (Pine), Camphor, Chinese fir (Fir), Schima, Leaf privet (Ligustrum quihoui Carr.), and Woodwardia (Woodwardia japonica (L.f.) Sm.). More information about the six species is shown in Table 1. The leaf privet and Woodwardia were abbreviated as Privet and Fern hereafter, respectively.

For each species, two plants at the similar growing status were chosen and labeled. Three small twigs (30-40 cm long, base canopies) were cut off from each of the pre-labeled plant, and then collected the leaves or needles excluding the petioles along the leaf edge. The air temperature and the relative humidity were recorded for two times on the sampling day, i.e., at the beginning and at the end of the sample process (lasting for about $2 \mathrm{~h}$ ). The average of air temperatures and the mean relative humidity within each of the sampling process are shown in Fig. 1, as well as the monthly mean temperature and the total precipitation during the experiment period (from June 2014 to May 2015).

All the leaves or needles were gently washed with distilled water and divided into two sub-samples. One sub-sample was frozen in liquid nitrogen immediately and thereafter stored in a refrigerator $\left(-80^{\circ} \mathrm{C}\right)$ before determination of the leaf tissue chlorophyll concentration, $\mathrm{NH}_{4}{ }^{+}$concentration, and $\mathrm{pH}$. The second sub-sample was dried for analyzing the relative water content, total nitrogen content (TN), and total carbon content (TC) of leaves or needles. 
Table 1 Basic information about the six experimental plant species

\begin{tabular}{llll}
\hline Plant species & Latin name & Leaf habits & Stand structure \\
\hline Masson pine & Pinus massoniana & Evergreen conifer & Macrophanerophytes \\
Camphor & Cinnamomum camphora & Evergreen broad-leaved & Macrophanerophytes \\
Chinese fir & Cunninghamia lanceolata & Evergreen conifer & Mesophanerophytes \\
Schima & Schima superba Gardn. et Champ. & Evergreen broad-leaved & Mesophanerophytes \\
Leaf privet & Ligustrum quihoui Carr. & Semi-evergreen broad-leaved & Shrub \\
Woodwardia & Woodwardia japonica (L.f.) Sm. & Evergreen & Pteridophyte \\
\hline
\end{tabular}

Notes: The Leaf privet is a deciduous or semi-evergreen plant, and at the Tieshanping catchment, it shows the characteristics of semi-evergreen plant

\section{Experimental design}

Two trials were designed to investigate the seasonal variations of $\mathrm{NH}_{3}$ emission potentials and $\mathrm{N}$ pools for the six dominant plant species (trial 1) and to understand the effect of leaf age on the $\mathrm{NH}_{3}$ emission potentials and $\mathrm{N}$ pools (trial 2).

\section{Trial 1: variations among seasons and species}

Trial 1 and trial 2 were conducted from June 2014 to April 2015 (between 9:00 am and 15:00 pm). In each season, at least three times of sampling were set up, and the sample intervals were half a month. Mature leaves or needles (fully developed green leaves or needles) of the six species were collected from the pre-labeled plants. Leaves or needles from the same plant were pooled into one sample.

\section{Trial 2: variations among different leaf ages}

Leaves or needles with different ages of the Schima, Camphor, Fir, and Pine were chosen as the experimental materials in this trial. Specifically, the leaves or needles were divided into four ages, including new green leaves (just budding or developing light green leaves, if present), mature leaves, senescent leaves (attached leaves with visual symptoms of senescence, if present), and fallen leaves (senescent or dead detached leaves). The fallen leaves were collected by nylon nets fixed under the labeled trees. For each leaf age, leaves or needles from the same labeled tree were mixed into one sample.

\section{Sample analysis}

Frozen leaf or needle materials were extracted and thoroughly grounded in a cooled mortar by $10 \mathrm{mM}$ formic acid for bulk
Fig. 1 The monthly mean temperature and the monthly total precipitation during the experiment period (from June 2014 to May 2015) (a), as well as the averages of air temperature and the mean relative humidity during each of the sampling process (lasting for about 2 h) (b)
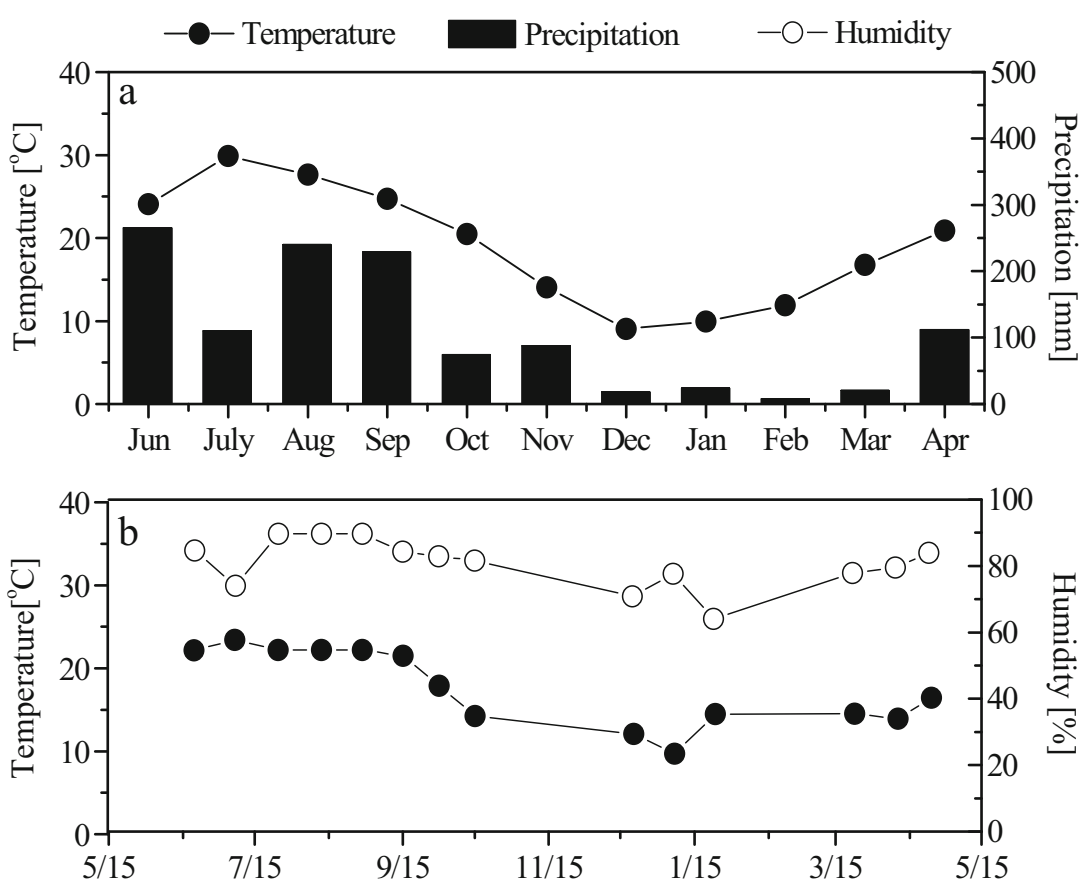
tissue $\mathrm{NH}_{4}{ }^{+}$concentration and by distilled water for bulk tissue proton activity $\left(\mathrm{H}^{+}=10^{-\mathrm{pH}}\right.$ ) (leaf to water ratio, 1:10). Thereafter, the suspensions were centrifuged for $10 \mathrm{~min}$ $\left(10,000 \mathrm{~g}, 4^{\circ} \mathrm{C}\right)$, and the supernatants were collected and filtered (using $0.45 \mu \mathrm{m}$ syringe filter) for analysis. Details of the analytical procedures can be obtained from Mattsson et al. (2009) and Wang et al. (2011). The $\mathrm{NH}_{4}{ }^{+}$concentration was analyzed by a continuous flow-injection analyzer $\left(\mathrm{San}^{++}\right.$, Skalar, The Netherlands). The tissue $\mathrm{pH}$ was determined by a $\mathrm{pH}$ meter (PHB-4).

Frozen materials were extracted by $96 \%(v / v)$ alcohol for analysis of tissue chlorophyll concentration (both chlorophylls a and b) by an ultraviolet-visible spectrophotometer (UV5100) (Zou 2000). The relative water content (\% of Fw) was obtained through drying fresh leaves or needles for $48 \mathrm{~h}$ at $70{ }^{\circ} \mathrm{C}$. After that, the dried leaves or needles were grounded and analyzed for leaf TN and TC contents (\% of Dw) using an element analyzer (Vario EL III, Elementar Analysen systeme GmbH, Germany).

\section{The calculation of $\mathrm{NH}_{3}$ emission potential}

$\mathrm{NH}_{3}$ emission potential $(\Gamma)$ was determined by using the leaf tissue $\mathrm{NH}_{4}{ }^{+}$and $\mathrm{H}^{+}$concentration (Mattsson and Schjoerring 2003; Wang et al. 2011) according to the equation:

$\Gamma=\frac{\left[N H_{4}^{+}\right]}{\left[H^{+}\right]}$

where $\left[\mathrm{NH}_{4}{ }^{+}\right]$and $\left[\mathrm{H}^{+}\right]$are the $\mathrm{NH}_{4}{ }^{+}$concentration and the proton activity $\left(\left[\mathrm{H}^{+}\right]=10^{-\mathrm{pH}}\right)$ in the leaf extracts, respectively.

\section{Data analysis}

Data were computed and analyzed by Microsoft Excel 2013 and SPSS 17.0 with significant differences at $p<0.05$ (oneway ANOVA, LSD) unless otherwise stated. Pearson's correlation analysis was used to gain the correlations between leaf $\mathrm{NH}_{3}$ emission potentials, $\mathrm{N}$ pools, and the effecting factors. Figures in the paper were drawn by Sigma plot 10.0 and Origin 8.0.

\section{Results}

Eight parameters were referred to, i.e., the leaf tissue $\mathrm{NH}_{4}{ }^{+}$ concentration, $\mathrm{pH}, \Gamma, \mathrm{N}$ content, the ratio of TC to TN $(\mathrm{C} / \mathrm{N}$ ratio), the concentration of chlorophyll $(\mathrm{Chl}(\mathrm{a}+\mathrm{b}))$, the ratio of chlorophyll a to chlorophyll $\mathrm{b}(\mathrm{Chl} \mathrm{a/b})$, and the relative water content. The leaf tissue $\mathrm{NH}_{4}{ }^{+}$concentration and $\mathrm{N}$ content represent the $\mathrm{N}$ status of plants, and $\Gamma$ value is a simple indicator to assess plants' ability or potential to emit $\mathrm{NH}_{3}$ to the atmosphere. The bigger the $\Gamma$ is, the more possibility of gaseous $\mathrm{NH}_{3}$ release from the plants to the air. The Chl $(\mathrm{a}+\mathrm{b})$ and $\mathrm{Chl} \mathrm{a} / \mathrm{b}$ ratio are useful indicators of the physiological activity and the degree of senescence. When the leaves senesce, the values of $\mathrm{Chl}(\mathrm{a}+\mathrm{b})$ and $\mathrm{Chl} \mathrm{a} / \mathrm{b}$ ratio may sharply decline.

\section{Variations among seasons and plant species}

Leaf tissue $\mathrm{NH}_{4}^{+}$concentration, $\mathrm{pH}$, and $\mathrm{NH}_{3}$ emission potential

The average leaf tissue $\mathrm{NH}_{4}{ }^{+}$concentrations of the six species presented small seasonal variations, which were 89.2, 101.6, 85.5, and 103.7 $\mu \mathrm{M}$ in spring (March to April), summer (June to August), autumn (September to October), and winter (December to January), respectively (Fig. 2a). For the plants Schima, Camphor, Fern, and Fir, the tissue pH (Fig. 2b) in spring and winter (average: 5.1) was generally higher than that in summer and autumn (average: 4.9). Consequently, the mean $\Gamma$ value of these species showed a slight increase in spring (20.1) and winter (32.0), corresponding to 10.1 and 15.3 in summer and autumn, respectively (Fig. 2c).

The variations of tissue $\mathrm{NH}_{4}{ }^{+}$concentration and $\mathrm{pH}$ among species were both significant. The Fir needles had the largest $\mathrm{NH}_{4}{ }^{+}$concentration (mostly $>200 \mu \mathrm{M}$ ), and nearly one order of magnitude higher than that in Schima and Camphor leaves. The average tissue $\mathrm{NH}_{4}{ }^{+}$concentrations of Schima, Camphor, Fern, Privet, and Pine ranged from 17.7 to $49.0 \mu \mathrm{M}$, differences among which were insignificant (Fig. 2a). The tissue $\mathrm{pH}$ of Schima and Pine was normally less than 4.6 (Fig. 2b) and clearly lower than that in the leaves or needles of the other four species (mostly $>5$ ). During spring, the average tissue $\mathrm{pH}$ in the Fir needles occupied 92.4 and $87.9 \%$ of that in the Fern and Privet leaves, during summer which accounted for 97.1 and $84.0 \%$ of that in the Fern and Privet leaves, respectively.

Clear variability of $\Gamma$ was observed among species (Fig. 2c). Generally, the Fir needles had the largest $\Gamma$ values (mostly $>30$ ) and significantly larger than those for the other five species. The Fern and the Privet were often the second and the third in $\Gamma$ values (about 20 and 15, respectively), the differences between which were normally significant. The Schima and the Pine leaves or needles mostly had small and comparable $\Gamma$ values $(<2)$.

\section{Chlorophyll}

The mean Chl $(\mathrm{a}+\mathrm{b})$ concentrations were 1.2, 1.4, 1.3, and $0.93 \mathrm{mg} \mathrm{g}^{-1} \mathrm{FW}$ in spring, summer, autumn, and winter, respectively (Fig. 3a). The $\mathrm{Chl} \mathrm{a} / \mathrm{b}$ ratios of the six species during the four seasons were in the ranges of 1.4-2.2, 1.3-2.1, 1.3-2.4, and 1.3-2.3, respectively (Fig. 3b).

Both the variations of Chl $(\mathrm{a}+\mathrm{b})$ concentration and $\mathrm{Chl} \mathrm{a} / \mathrm{b}$ ratio among plant species were obvious. The mean $\mathrm{Chl}(\mathrm{a}+\mathrm{b})$ 
Fig. 2 Seasonal variations of leaf tissue $\mathrm{NH}_{4}{ }^{+}$concentrations (a), $\mathrm{pH}(\mathbf{b})$, and $\mathrm{NH}_{3}$ emission potentials (c) of the six plant species

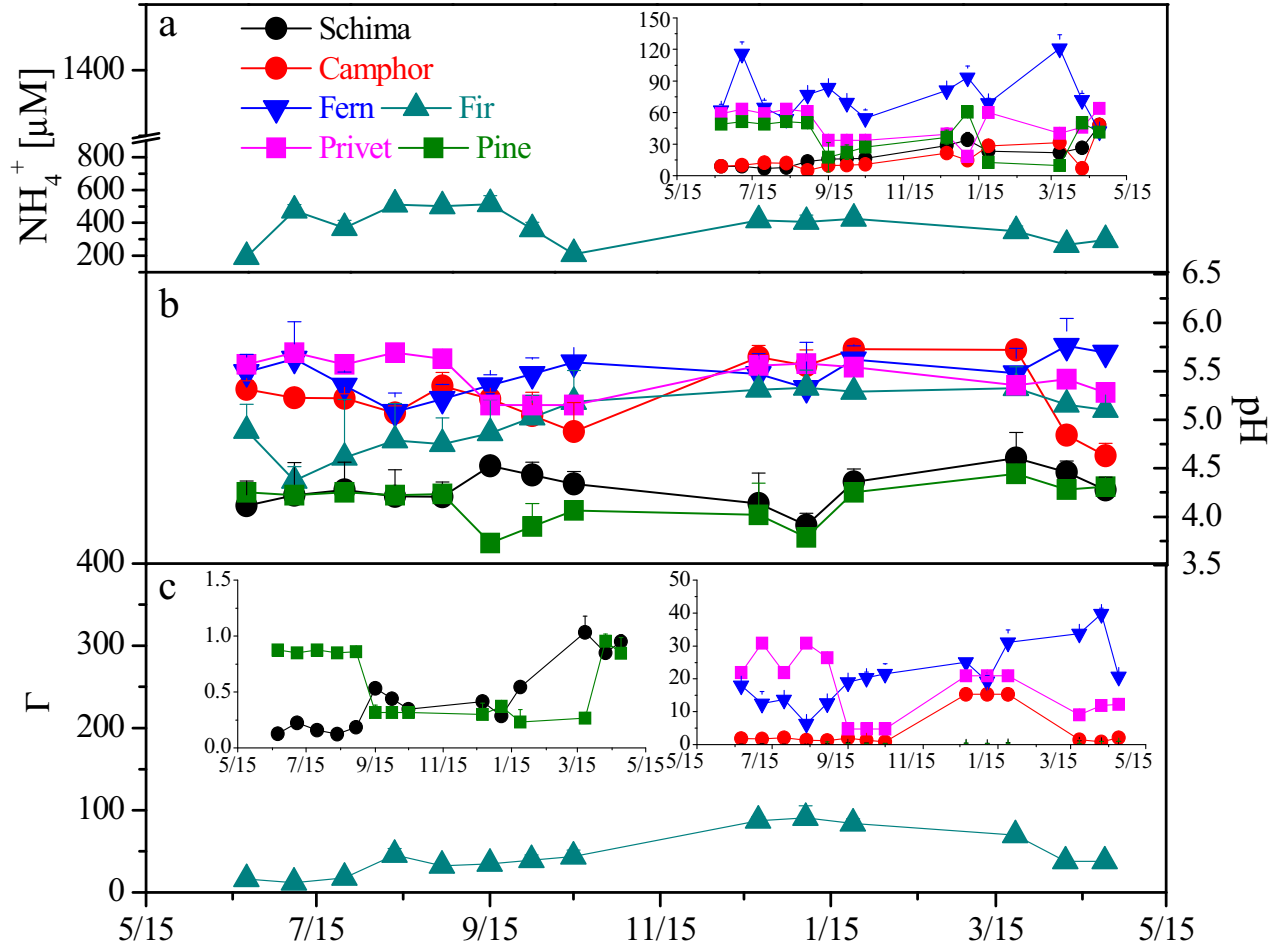

Notes: The values are means $(n=2)$, and the error bars represent standard errors. concentrations of the six species could be divided into four classes, and the Fern leaves (the first class) had the largest Chl $(\mathrm{a}+\mathrm{b})$, i.e., $1.6 \mathrm{mg} \mathrm{g}^{-1} \mathrm{Fw}$. The second class contained the Schima and Privet, both having the concentrations of
$1.3 \mathrm{mg} \mathrm{g}^{-1}$ Fw. The third class included Camphor and Fir (1.1 $\mathrm{mg} \mathrm{g}^{-1} \mathrm{Fw}$ on average). Pine was the last class with the concentration of $0.67 \mathrm{mg} \mathrm{g}^{-1} \mathrm{FW}$. Differences between the last class and the other three ones and between the first and the
Fig. 3 Seasonal variations of leaf tissue chlorophyll $(\mathrm{a}+\mathrm{b})$ concentrations (a) and chlorophyll $\mathrm{a} / \mathrm{b}$ ratios $(\mathbf{b})$ of the six plant species

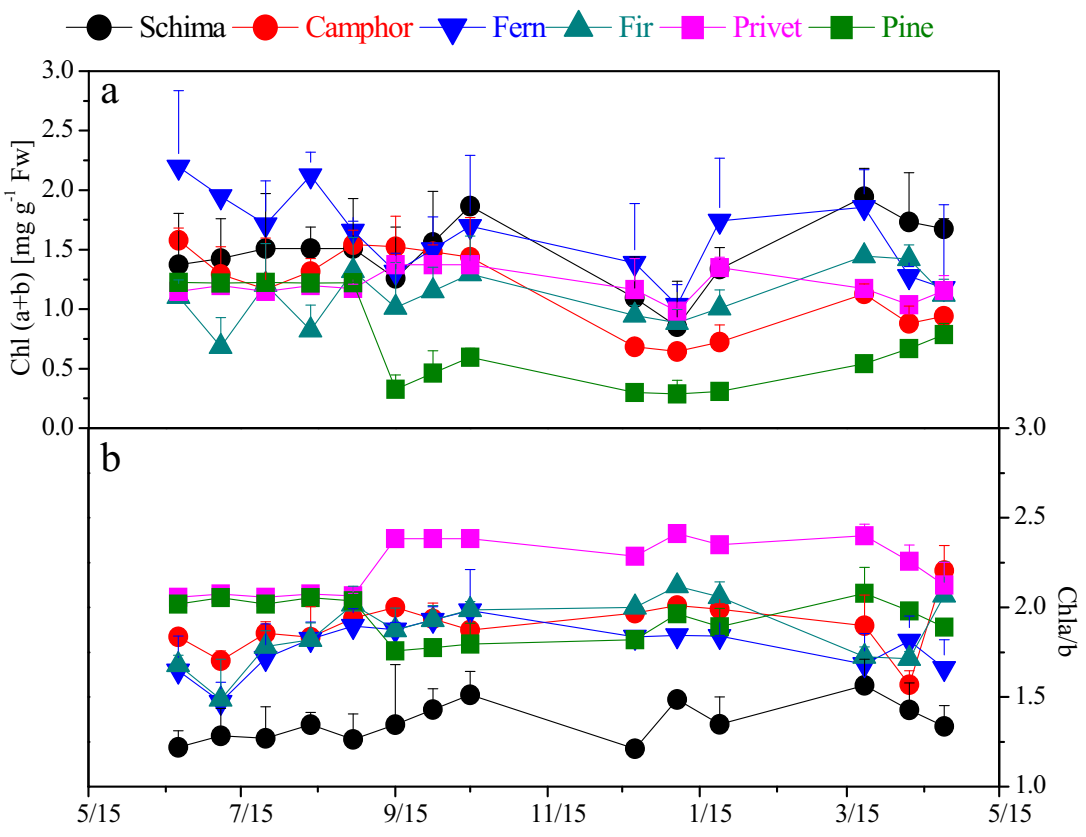

Notes: The values are means $(n=2)$, and the error bars represent standard errors. 
Fig. 4 Seasonal variations of leaf tissue $\mathrm{N}$ contents $(\mathbf{a})$ and $\mathrm{C} / \mathrm{N}$ ratios $(\mathbf{b})$ of the six plant species

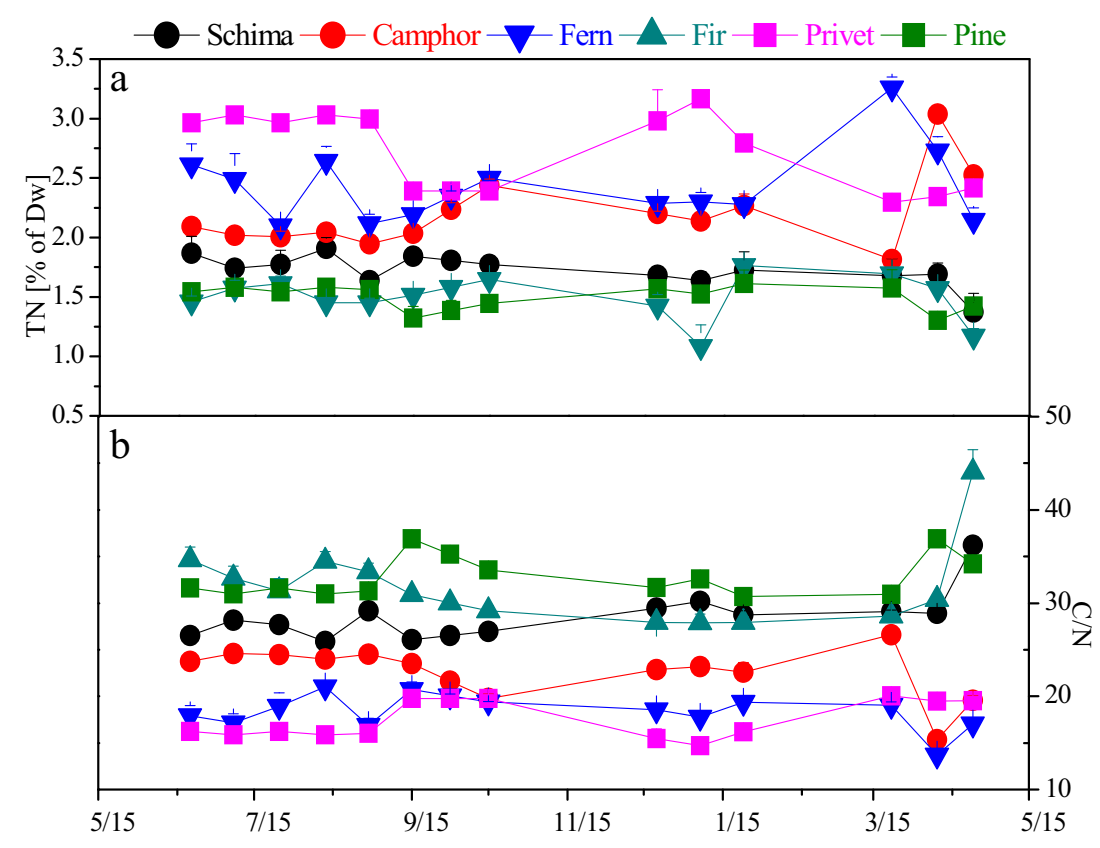

Notes: The values are means $(\mathrm{n}=2)$, and the error bars represent standard errors. third class were both significant. The averages $\mathrm{Chl} \mathrm{a} / \mathrm{b}$ of the six species were in the range of 1.4-2.3, and the Privet leaves had the highest ratio, which was significantly higher than that in the Schima. The $\mathrm{Chl} \mathrm{a} / \mathrm{b}$ ratios in the other four species were in moderate and comparable.

\section{$N$ content and $C / N$ ratio}

The average of tissue $\mathrm{N}$ contents for the six plant species were 2.1, $2.0,1.9$, and $2.1 \%$ of Dw in spring, summer, autumn, and winter, respectively (Fig. 4a). The average $\mathrm{C} / \mathrm{N}$ ratios of the six plants in autumn and winter were 8.2 and $7.4 \%$ lower than those in spring and 5.7 and $4.9 \%$ lower than summer (Fig. 4b).

Variations of tissue $\mathrm{N}$ content and $\mathrm{C} / \mathrm{N}$ ratio were mostly significant among species, and the Fern and the Privet leaves had higher $\mathrm{N}$ content on average ( 2.4 and $2.7 \%$ of Dw, respectively) (Fig. 4a). Contrarily, the Fir and the Pine needles had lower mean $\mathrm{N}$ contents, i.e., 1.6 and $1.5 \%$ of $\mathrm{Dw}$, respectively. The Schima and the Camphor leaves had the moderate mean $\mathrm{N}$ contents, i.e., 1.7 and $2.3 \%$, respectively. Correspondingly, the
Fig. 5 The effect of leaf age on $\mathrm{NH}_{3}$ emission potentials of Schima (a), Camphor (b), Fir (c), and Pine (d)

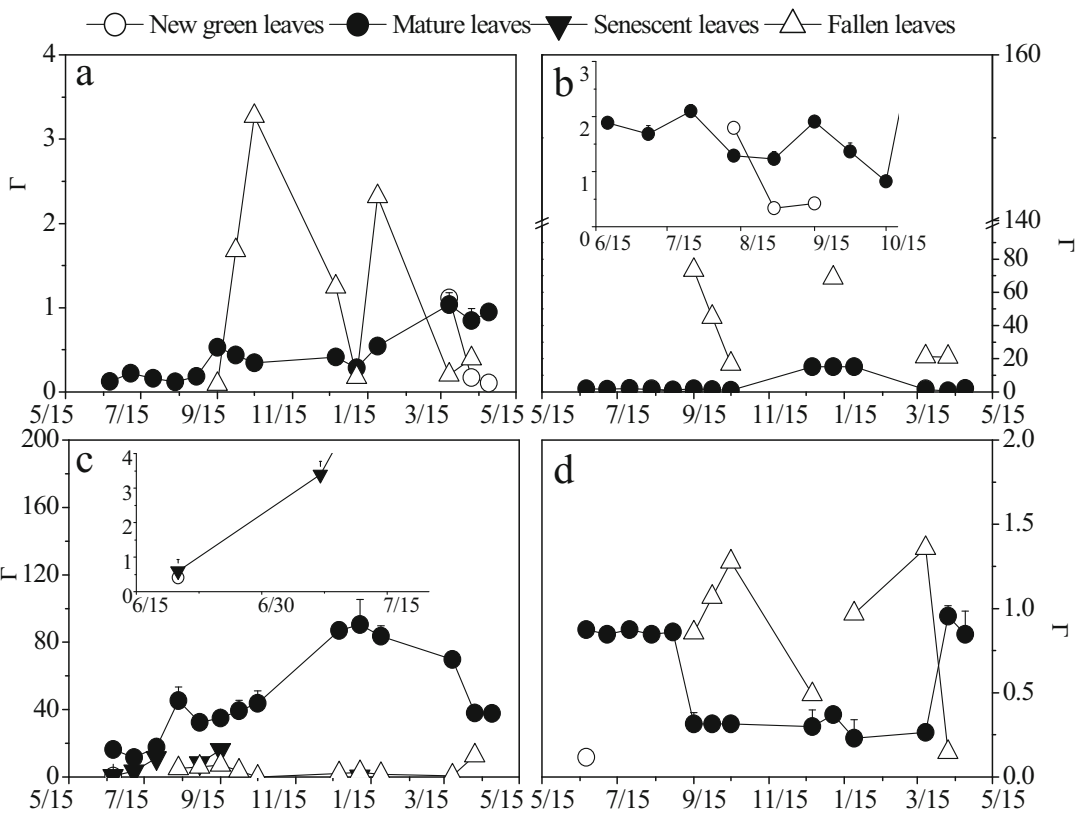


$\mathrm{C} / \mathrm{N}$ ratios of the leaf tissue were higher in the Fir and Pine (mostly $>30$ ), lower in the Fern and Privet (mostly <20) (Fig. 4b), yet moderate in the Schima and Camphor.

\section{Effects of leaf age on $\mathrm{NH}_{3}$ emission potential, $\mathrm{N}$ content, and $\mathrm{C} / \mathrm{N}$ ratio}

\section{$\mathrm{NH}_{3}$ emission potential}

$\Gamma$ values of the Schima, Camphor, Fir, and Pine trees with different leaf ages are shown in Fig. 5. The average $\Gamma$ values for fallen leaves or needles of the Schima, Camphor, and Pine were 149,807 , and $86.1 \%$ higher than the corresponding mature parts (Fig. 5a, b, d). The new green leaves or needles sometimes had lower $\Gamma$ than those at the mature stage, but this pattern was not consistent. The mean $\Gamma$ values (46.2) in the mature Fir needles were significantly higher than those in the new green, the senescent, and the fallen parts (Fig. 5c), which in the later three were comparable and without significant differences, i.e., $0.41,6.7$, and 4.1 , respectively.

\section{$N$ content and $C / N$ ratio}

The average $\mathrm{N}$ contents of the fall leaves or needles of the Schima, Camphor, and Pine were 1.1, 1.8, and 1.1\% of Dw, respectively, and clearly lower than those in the mature parts $(1.7,2.3$, and $1.5 \%$, respectively) (Fig. 6a, b, d). The new green Camphor leaves had the highest $\mathrm{N}$ content among the three ages, i.e., $2.6 \%$ on average (Fig. 6b).

Contrary to the $\mathrm{N}$ distribution during different leaf age, the fallen leaves or needles of the Schima, Camphor, and Pine
(Fig. 7a, b, d) had the largest mean $\mathrm{C} / \mathrm{N}$ ratios (39.9), which were 47.0 and $53.7 \%$ larger than those in the mature and the new green parts, respectively. The difference between the new green and the mature leaves or needles of these species was negligible, and the lowest $\mathrm{C} / \mathrm{N}$ ratio (15.5) was observed in the new green leaves of Camphor during spring (Fig. 7b). The variations of $\mathrm{N}$ content and $\mathrm{C} / \mathrm{N}$ ratio among different Fir needle ages were small (Figs. 6c and 7c).

\section{Discussion}

In this study, temporal variations of $\Gamma$ values and $\mathrm{N}$ pools were assessed for the six dominant plant species grown in a subtropical forested catchment, southwest China. Meanwhile, the effects of leaf age on them were also investigated. Consequently, we could identify the source or sink functions of plant canopies on the atmogenic $\mathrm{NH}_{3}$ at the catchment preliminarily.

The $\Gamma$ values for the mature leaves or needles of the six plant species ranged from 0.12 to 90.5 in this study (Fig. 2c), which were far smaller than those observed in grass or crop species (Mattsson and Schjoerring 2003; Sutton et al. 2001), and yet comparable to those recorded in temperate forests, i.e., 20-120 for Douglas fir (Pseudotsuga menziesii (Mirb.) Franco) and 10-40 for Scots pine (Pinus sylvestris L.) needles (Wang et al. 2013). In the present study, the tissue $\mathrm{NH}_{4}{ }^{+}$concentration and $\mathrm{N}$ content of the six species showed small seasonal variations (Figs. 2a and $4 a$ ). The $\Gamma$ value of the Schima, Camphor, Fern, and Fir during spring and summer presented a little increase with a slight rise of tissue $\mathrm{pH}$ in these two
Fig. 6 The effect of leaf age on tissue $\mathrm{N}$ contents of Schima (a), Camphor (b), Fir (c), and Pine (d)

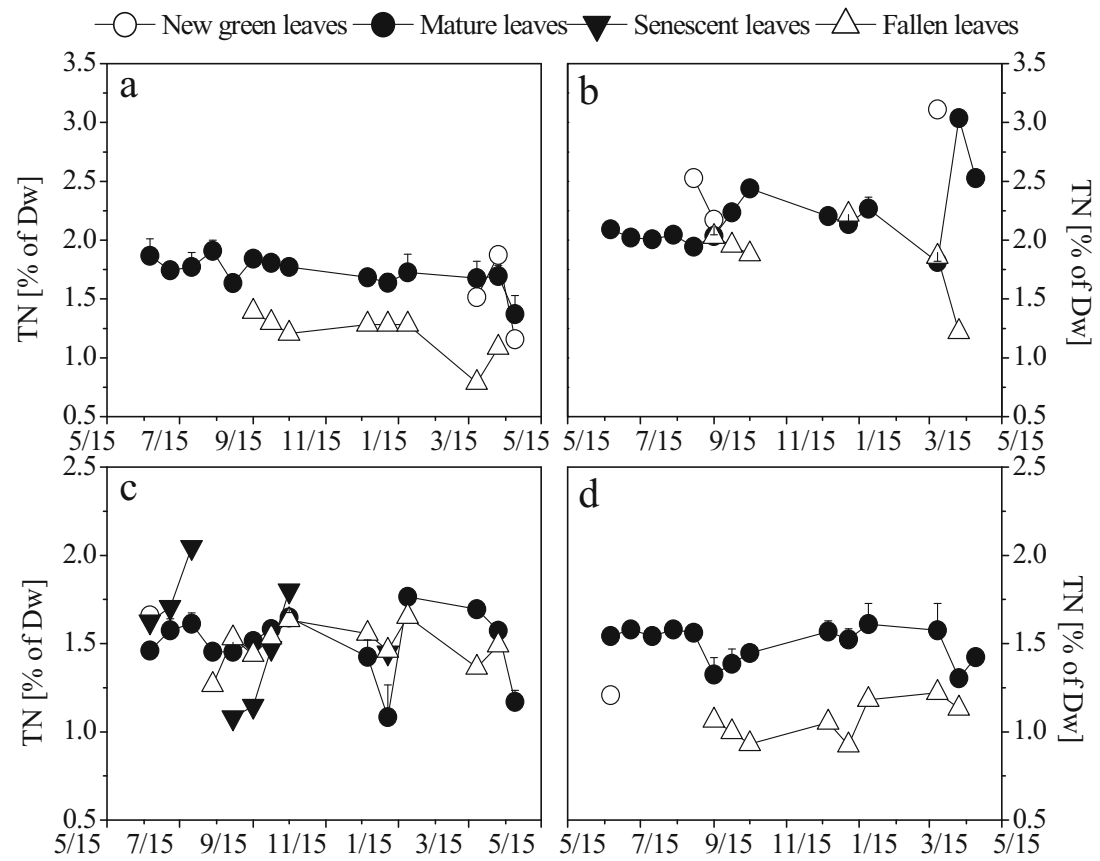


Fig. 7 The effect of leaf age on $\mathrm{C} / \mathrm{N}$ ratios of Schima (a),

Camphor (b), Fir (c), and Pine (d)

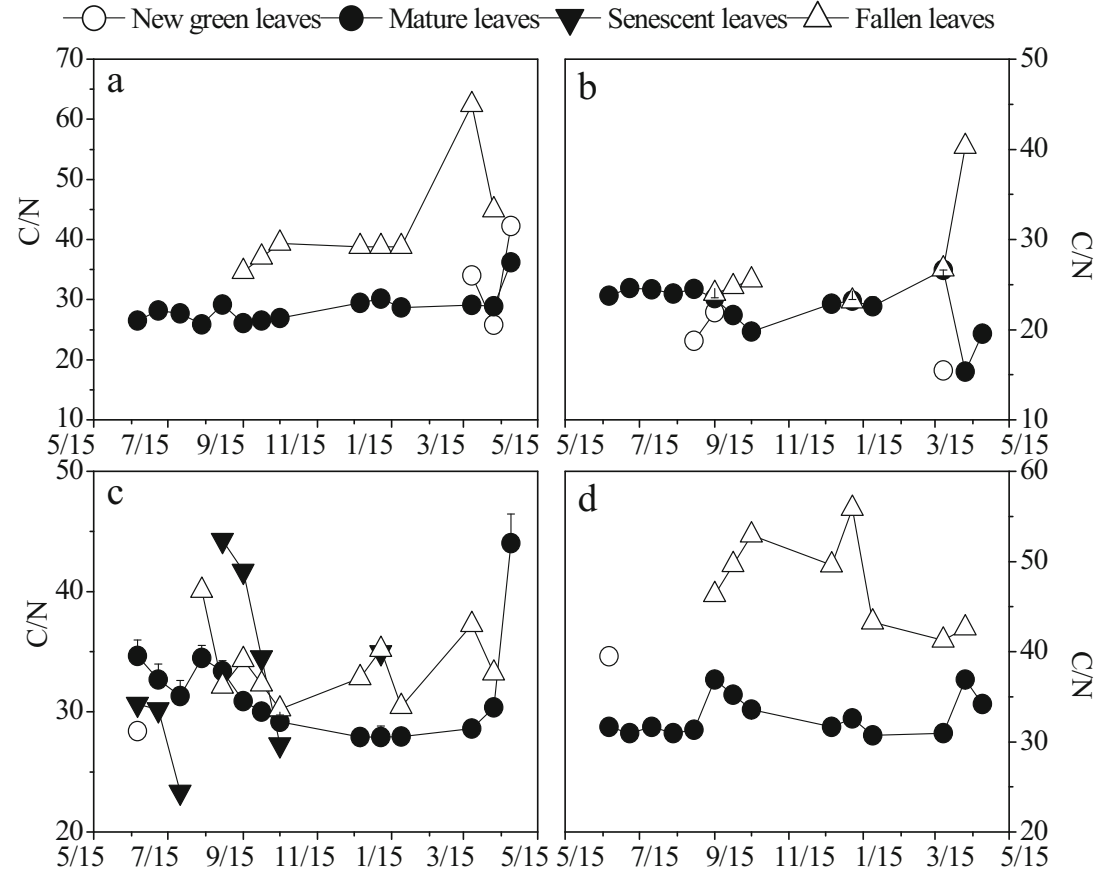

seasons (Fig. 2b, c). However, compared to the clear variability of $\Gamma$ value among different leaf ages and plant species, this limited increase seemed negligible. In comparison with the deciduous, the evergreen species tended to retain much more foliage $\mathrm{N}$ within plants and therefore presented smaller seasonal fluctuation in N pools (Wang et al. 2013). These could be used to explain the unclear variations of foliage $\Gamma$ values and $\mathrm{N}$ pools among seasons in this study, because the six species were all evergreen (Table 1). In addition, the fluctuations of air temperature in temperate forests throughout the whole year reported by Wang et al. (2013) were more than $25^{\circ} \mathrm{C}$ with minus temperature in winter. Contrarily, in a subtropical forest in this study, the difference in air temperature between the hottest sampling day and the coldest was $13.7^{\circ} \mathrm{C}$ with a minimum temperature of about $10{ }^{\circ} \mathrm{C}$ (Fig. 1b). We supposed that this range of temperatures was not low enough to lead to leaf senescence since small fluctuations of chlorophyll concentration and ratio in time scales were observed in the present study (Fig. 3 and Fig. S4c, d), which may probably result in the small variability of $\Gamma$ values and $\mathrm{N}$ pools among seasons. Other possible explanation for the small temporal variability of foliage $\Gamma$ values and $\mathrm{N}$ pools might be the low forest health status at the TSP catchment, especially the high defoliation percentage and mortality of Masson pine, which may in turn lead to the low transformation rate of $\mathrm{N}$ nutrients within the plants ( $\mathrm{Li}$ et al. 2014; Wang et al. 2007).

As mentioned above, the variability of $\Gamma$ values of mature leaves or needles between different plant species in this study was clear in all seasons (Fig. 2c), whereas this differences were not linked to the air concentrations of $\mathrm{NH}_{3}$ which fluctuated in a small range during the experiment (1.91$2.89 \mathrm{nmol} \mathrm{mol}^{-1}$ ) at the TSP catchment. The significant variability in $\Gamma$ values may affect by a range of species-dependent physiological processes involved in $\mathrm{N}$ uptake and $\mathrm{N}$ turnover in the leaves, which also reflect the foliage $\mathrm{N}$ status and the distribution of these two parameters across the plant species. In the present study, higher $\Gamma$ value in one species did not correspond to higher N content, and Pearson's correlation analysis showed that leaf tissue $\mathrm{NH}_{4}{ }^{+}$concentration and $\mathrm{N}$ content were negatively correlated $(r=-0.16, p=0.005)$. This suggested that the $\mathrm{N}$ content in leaf could not be used to assess the plants' potential to emit $\mathrm{NH}_{3}$ at TSP, and a similar conclusion was obtained in an intensively managed grassland by Van Hove et al. (2002).

Leaf senescence represents the final stage of leaf development and is characterized by the transition from nutrient assimilation to nutrient remobilization (Masclaux et al. 2000). $\mathrm{NH}_{4}{ }^{+}$is re-assimilated into amino acids when exported from the senescing leaves and may also be lost through leaching or volatilization of gaseous $\mathrm{NH}_{3}$ (Schjoerring and Mattsson 2001). During senescent, the massive release of $\mathrm{NH}_{3}$ was synchronized with protein and chlorophyll degradation (Mattsson and Schjoerring 1997; Schjoerring et al. 1998). In this study, both the $\Gamma$ value and $\mathrm{N}$ content varied among different leaf ages (Figs. 5 and 6), and the new green leaves or needles of Schima, Camphor, and Pine normally had lower $\Gamma$. Furthermore, the $\Gamma$ values in the fallen leaves or needles of these species were generally higher than those at the mature period, which were in line with the findings in senescent ryegrass leaves reported by Mattsson and Schjoerring (2003) 
in a laboratory experiment and by Wang and Schjoerring (2012) in a field study. Meanwhile, the tissue Chl $(\mathrm{a}+\mathrm{b})$ concentration and the $\mathrm{Ch}$ a/b ratio in senescent and fallen leaves or needles declined clearly (Fig. S3), which probably lead to the accumulation of $\mathrm{NH}_{4}{ }^{+}$in those tissues, especially for the Camphor trees (Fig. S1b). Additionally, it was the high $\mathrm{pH}$ in fallen leaves or needles that mainly resulted in the high $\Gamma$ in these aged tissues (Fig. S2). Wang et al. (2013) observed an increase of tissue $\mathrm{NH}_{4}{ }^{+}$concentration, but a decrease of tissue $\mathrm{pH}$ thus terminally resulted in the decline of $\Gamma$ during senescence of the beech leaves. Moreover, it was possible that the decline of chloroplastic glutamine synthetase activity in aged leaves also contributed to the increase of $\Gamma$ in these tissues (Duan et al. 2012; Mattsson and Schjoerring 1997). Notably, the $\Gamma$ of the mature Fir needles was generally the highest among the four ages (Fig. 5c), and the high $\mathrm{NH}_{4}{ }^{+}$concentration (Fig. S1c) in the mature parts was the main reason. Small variability of tissue $\mathrm{N}$ content in the Fir among different ages was observed (Fig. 6c), implying that the senescence-induced $\mathrm{N}$ remobilization within this species was not obvious.

Increases in $\Gamma$ value may reduce the capacity of forests to act as sinks for the atmogenic $\mathrm{NH}_{3}$ or even give rise to a release of gaseous $\mathrm{NH}_{3}$ from plants to the surrounding atmosphere (Wang et al. 2013). The $\Gamma$ values of the green leaves were about 2600 in an intensively managed grassland (David et al. 2009) and around 2200 in a non-fertilized grassland (Kruit et al. 2007). Wang and Schjoerring (2012) suggested that the senescent grass leaves in all cases had much higher $\Gamma$ than the green plant tissues $(<3000)$. And in these ranges of $\Gamma$ value, green leaves are clearly sinks for the atmogenic $\mathrm{NH}_{3}$ (David et al. 2009; Herrmann et al. 2009). However, the biggest $\Gamma$ in our study was never exceeded 200 , which for the Masson pine needles was less than 2 (Figs. 2c and 5). This relatively low $\Gamma$ suggested the difficulty of $\mathrm{NH}_{3}$ emitting from the plants, because the values were too small to build up sufficiently high $\mathrm{NH}_{3}$ partial pressures in the leaves or needles. With respect to the vast planting areas of the six species at the TSP catchment (Wang et al. 2007), the Masson pine dominant subtropical forest there, was not likely to be a mainly atmogenic $\mathrm{NH}_{3}$ source. Moreover, Massad et al. (2010) established a clearly exponential relationship between the leaf tissue $\mathrm{NH}_{4}{ }^{+}$and the stomatal $\mathrm{NH}_{3}$ emission potential (the ratio of apoplastic $\mathrm{NH}_{4}{ }^{+}$to $\mathrm{H}^{+}$concentration). According to this correlation, the average of the stomatal compensation point $\left(\chi_{\mathrm{s}}\right)$ of Masson pine needles in the present study was estimated, i.e., $0.38 \mathrm{nmol} \mathrm{mol}^{-1}$, which was much lower than the seasonal mean concentrations of the atmospheric $\mathrm{NH}_{3}$ measured at TSP. Additionally, by applying the single-layer resistance model (Massad et al. 2010; Nemitz et al. 2000b; Schrader et al. 2016), the stomatal conductance reported by Zhang (2013) and the leaf area index of Masson pine at the TSP catchment (Wang 2012), we can estimate the $\mathrm{NH}_{3}$ uptake flux through the stomata (the model details are shown in the
Supporting material). The fluxes were ranging in $0.4-2.3 \mathrm{~kg}$ $\mathrm{NH}_{3}-\mathrm{N} \mathrm{ha}^{-1}$ year ${ }^{-1}$, accounting for $1.5-8.5 \%$ of $\mathrm{NH}_{4}{ }^{+}-\mathrm{N}$ deposition at TSP $\left(27.2 \mathrm{~kg} \mathrm{~N}^{-1}\right.$ year $^{-1}$, yearly average of data from 2012 to 2014, unpublished). These indicate that using the $\mathrm{N}$ flux in throughfall only leads to a significant underestimation of total $\mathrm{N}$ input in this ecosystem. However, using the values of the stomatal conductance measured by Zhang (2013) leads to some uncertainty on the estimation of the stomatal flux owing to the differences in plant-growing status. Researches should be conducted in future to determine more accurate stomatal conductance at the TSP catchment.

Also, the absorption of gaseous $\mathrm{NH}_{3}$ through leaf cuticles was quite possible with respect to the much precipitation, the high air humidity (mostly $>75 \%$ ) (Fig. 1), and the high relative water content of the leaves or needles in this study (range: $54.9-86.3 \%$ in mature tissues). When the relative air humidity is higher than $70 \%$, gaseous $\mathrm{NH}_{3}$ may deposit to the leaf surface efficiently (Kruit et al. 2008; van Hove et al. 1989). From these point of views, the present local $\mathrm{N}$ budget based on throughfall input only is quite problematic. The gaseous $\mathrm{NH}_{3}$ uptake through leaf stomata or cuticles contributes largely to the reactive $\mathrm{N}$ input at the TSP catchment.

However, the estimation of plants' functioning on the atmogenic $\mathrm{NH}_{3}$ through $\Gamma$ values was preliminary and with some degree of uncertainties. Some researchers suggested that the foliage $\Gamma$ value cannot be used as a tool to predict the potential $\mathrm{NH}_{3}$ exchange of beech leaves, because the fluctuations of $\Gamma$ did not match the $\mathrm{NH}_{3}$ exchange patterns through the chamber method (Wang et al. 2011). However, David et al. (2009) had found a clear relationship between $\chi_{\mathrm{s}}$ (estimated from bulk tissue $\mathrm{NH}_{4}{ }^{+}$ and bulk $\mathrm{pH}$ ) and $\mathrm{NH}_{3}$ fluxes (chamber method), who suggested that the bulk extraction methods were sufficient to identify the main sources and sinks within the grass canopies. Furthermore, a series of researches reported that the bulk tissue $\mathrm{NH}_{4}{ }^{+}$, apoplastic $\mathrm{NH}_{4}{ }^{+}$, and the $\chi_{\mathrm{s}}$ were significantly correlated (Hill et al. 2002; Massad et al. 2010; Mattsson and Schjoerring 2002; Mattsson et al. 2009), and positive correlation was also observed between the apoplastic $\mathrm{pH}$ and the bulk $\mathrm{NH}_{4}{ }^{+}$concentration (Loubet et al. 2002). Additionally, the dynamic chamber technique itself may overestimate the $\mathrm{NH}_{3}$ exchange between the plants and the atmosphere, and it was hard to separate the foliage $\mathrm{NH}_{3}$ emission from those emitted by litter leaves or soils (Hill et al. 2001; Mattsson et al. 2009). Therefore, the foliage $\Gamma$ have proven to be a promising and convenient indicator to identify the potential source or sink of subtropical forest for the atmogenic $\mathrm{NH}_{3}$ at the TSP catchment when the $\chi_{\mathrm{s}}$ or flux measurements are absent.

\section{Conclusions}

Variations of leaf tissue $\mathrm{NH}_{4}{ }^{+}$concentrations and $\mathrm{pH}$ among species resulted in very different $\mathrm{NH}_{3}$ emission potentials. The Fir and Fern leaves or needles had high $\mathrm{NH}_{3}$ emission potentials, 
which for the Pine and Schima were quite low. Higher potential $\mathrm{NH}_{3}$ emission did not coincide with higher tissue $\mathrm{N}$ content in plants. Specifically, the Fir and Pine needles had relatively low N contents, which in the Privet and Fern leaves were higher. Small seasonal variability in $\mathrm{NH}_{3}$ emission potentials and $\mathrm{N}$ pools was observed. Generally, fallen leaves or needles had larger $\mathrm{NH}_{3}$ emission potentials compared to those at the mature stage. However, the absolute values of $\mathrm{NH}_{3}$ emission potential of the six species were all too low to build up a sufficiently high $\mathrm{NH}_{3}$ partial pressure in the leaves or needles. Therefore, the Masson pine dominant subtropical evergreen forest at the TSP catchment functions as a sink for the atmospheric $\mathrm{NH}_{3}$, indicating that using the $\mathrm{N}$ flux in the throughfall only to stand for the whole reactive $\mathrm{N}$ input leads to an underestimation, thereby affects the accuracy of N budget in this ecosystem. This is quite valuable when modeling the leaf-atmosphere $\mathrm{NH}_{3}$ exchange in forests, and when estimating catchment or regional scales $\mathrm{N}$ budget.

Acknowledgments This work was supported by Sino-Norwegian collaboration project (CAS No. GJHZ1205/NRC No. 209696/E10) and the National Basic Research Program of China (2014CB953802). We would like to thank Tang Xiong at the Research Center for Eco-Environmental Sciences, Chinese Academy of Sciences, for her assistance in the lab experiment. The two anonymous reviewers are also acknowledged for their valuable comments.

\section{References}

Allen R, Myles L, Heuer MW (2011) Ambient ammonia in terrestrial ecosystems: a comparative study in the Tennessee Valley, USA. Sci Total Environ 409:2768-2772. doi:10. 1016/j.scitotenv.2011.04.017

Beusen AHW, Bouwman AF, Heuberger PSC, Van Drecht G, Van Der Hoek KW (2008) Bottom-up uncertainty estimates of global ammonia emissions from global agricultural production systems. Atmos Environ 42:6067-6077. doi:10.1016/j.atmosenv.2008.03.044

Chen X, Mulder J (2007) Atmospheric deposition of nitrogen at five subtropical forested sites in South China. Sci Total Environ 378: 317-330. doi:10.1016/j.scitotenv.2007.02.028

David M, Loubet B, Cellier P, Mattsson M, Schjoerring JK, Nemitz E, Roche R, Riedo M, Sutton MA (2009) Ammonia sources and sinks in an intensively managed grassland canopy. Biogeosciences 6: 1903-1915. doi:10.5194/bg-6-1903-2009

Dong W, Xing J, Wang S (2010): Temporal and spatial distribution of anthropogenic ammonia emissions in China: 1994-2006. Chi J Environ Sci 31, 1457-1463 (in Chinese with English abstract).doi: 10.13227/j.hjkx.2010.07.008

Duan W, Yang T, Dai Y, Li D, Zhang X, Liu H, Li N, Wang CG (2012) Stomatal $\mathrm{NH}_{3}$ compensation point and its metabolic regulation in senescence phenotypes of Nicotiana tabacum. Biol Plantarum 56: 771-774. doi:10.1007/s10535-012-0141-z

Flechard CR, Massad RS, Loubet B, Personne E, Simpson D, Bash JO, Cooter EJ, Nemitz E, Sutton MA (2013) Advances in understanding, models and parameterizations of biosphere-atmosphere ammonia exchange. Biogeosciences 10 : 5183-5225. doi:10.5194/bg-10-5183-2013

Geßler A, Rienks M, Rennenberg $\mathrm{H}(2000) \mathrm{NH}_{3}$ and $\mathrm{NO}_{2}$ fluxes between beech trees and the atmosphere-correlation with climatic and physiological parameters. New Phytol 147:539-560. doi:10.1046/ j.1469-8137.2000.00712.x

Hansen K, Sorensen LL, Hertel O, Geels C, Skjoth CA, Jensen B, Boegh E (2013) Ammonia emissions from deciduous forest after leaf fall. Biogeosciences 10:4577-4589. doi:10.5194/bg-10-4577-2013

Herrmann B, Mattsson M, Jones SK, Cellier P, Milford C, Sutton MA, Schjoerring JK, Neftel A (2009) Vertical structure and diurnal variability of ammonia exchange potential within an intensively managed grass canopy. Biogeosciences 6:15-23. doi: 10.5194/bg-6-15-2009

Hill PW, Raven JA, Loubet B, Fowler D, Sutton MA (2001) Comparison of gas exchange and bioassay determinations of the ammonia compensation point in Luzula sylvatica (Huds.) gaud. Plant Physiol 125: 476-487. doi:10.1104/pp.125.1.476

Hill PW, Raven JA, Sutton MA (2002) Leaf age-related differences in apoplastic $\mathrm{NH}_{4}^{+}$concentration, $\mathrm{pH}$ and the $\mathrm{NH}_{3}$ compensation point for a wild perennial. J Exp Bot 53: 277-286. doi:10.1093/jexbot/53.367.277

van Hove LWA, Adema EH, Vredenberg WJ, Pieters GA (1989) A study of the adsorption of $\mathrm{NH}_{3}$ and $\mathrm{SO}_{2}$ on leaf surfaces. Atmos Environ 23:1479-1486. doi:10.1016/0004-6981(89)90407-1

van Hove LWA, Heeres P, Bossen ME (2002) The annual variation in stomatal ammonia compensation point of ryegrass (Lolium perenne $L$.) leaves in an intensively managed grassland. Atmos Environ 36: 2965-2977. doi:10.1016/S1352-2310(02)00242-X

Huang X, Song Y, Li MM, Li JF, Huo Q, Cai XH, Zhu T, Hu M, Zhang HS (2012) A high-resolution ammonia emission inventory in China. Global Biogeochem Cy 26:GB1030. doi:10.1029/2011 gb004161

Jiang C, Zhang X (2008) N isotopes and N cycle in the TieShanPing subtropical forest ecosystem, southwestern China. Environ Monit Assess 154:301-308. doi:10.1007/s10661-008-0398-Z

Kruit RJW, van Pul WAJ, Otjes RP, Hofschreuder P, Jacobs AFG, Holtslag AAM (2007) Ammonia fluxes and derived canopy compensation points over non-fertilized agricultural grassland in the Netherlands using the new gradient ammonia - high accuracy monitor (GRAHAM). Atmos Environ 41:1275-1287. doi:10. 1016/j.atmosenv.2006.09.039

Kruit RJW, Jacob AFG, Holtslaga AAM (2008) Measurements and estimates of leaf wetness over agricultural grassland for dry deposition modeling of trace gases. Atmos Environ 42:5304-5316. doi:10. 1016/j.atmosenv.2008.02.061

Krupa SV (2003) Effects of atmospheric ammonia $\left(\mathrm{NH}_{3}\right)$ on terrestrial vegetation: a review. Environ Pollut 124:179-221. doi:10.1016/S0269-7491(02)00434-7

Li Z, Wang Y, Liu Y, Guo H, Li T, Li Z, Shi G (2014) Longterm effects of liming on health and growth of a masson pine stand damaged by soil acidification in Chongqing, China. PLoS One 9:e94230. doi:10.1371/journal.pone.0094230

Loubet B, Milford C, Hill PW, Sim Tang Y, Cellier P, Sutton MA (2002) Seasonal variability of apoplastic $\mathrm{NH}_{4}{ }^{+}$and $\mathrm{pH}$ in an intensively managed grassland. Plant Soil 238:97-110. doi: 10.1023/a:1014208926195

Lun X, Zhang X, Mu Y, Anpu N, Anpu JG (2003) Size fractionated speciation of sulfate and nitrate in airborne particulates in Beijing, China. Atmos Environ 37:2581-2588. doi:10. 1016/s1352-2310(03)00220-6

Masclaux C, Valadier MH, Brugiere N, Morot-Gaudry JF, Hirel B (2000) Characterization of the sink/source transition in tobacco (Nicotiana tabacum L.) shoots in relation to nitrogen management and leaf senescence. Planta 211:510-518. doi:10.1007/s004250000310

Massad RS, Nemitz E, Sutton MA (2010) Review and parameterisation of bi-directional ammonia exchange between vegetation and the atmosphere. Atmos Chem Phys 10:10359-10386. doi:10.5194/ acp-10-10359-2010

Mattsson M, Schjoerring JK (1996) Ammonia emission from young barley plants: influence of $\mathrm{N}$ source, light/dark cycles 
and inhibition of glutamine synthetase. J Exp Bot 47:477484. doi:10.1093/jxb/47.4.477

Mattsson M, Schjoerring J (1997) Ammonia exchange between plants and the atmosphere: Effects of ammonium supply to the roots, darkinduced senescence and reduced GS activity. In: Ando T et al. (Editors), Plant Nutrition for Sustainable Food Production and Environment. Developments in Plant and Soil Sciences. Springer Netherlands, pp. 827-831

Mattsson M, Schjoerring JK (2002) Dynamic and steady-state responses of inorganic nitrogen pools and $\mathrm{NH}_{3}$ exchange in leaves of Lolium perenne and Bromus erectus to changes in root nitrogen supply. Plant Physiol 128:742-750. doi:10.1104/pp.010602

Mattsson M, Schjoerring JK (2003) Senescence-induced changes in apoplastic and bulk tissue ammonia concentrations of ryegrass leaves. New Phytol 160:489-499. doi:10.1046/j.14698137.2003.00902.X

Mattsson M, Herrmann B, Jones S, Neftel A, Sutton MA, Schjoerring JK (2009) Contribution of different grass species to plant-atmosphere ammonia exchange in intensively managed grassland. Biogeosciences 6:59-66. doi:10.5194/bg-6-59-2009

Neirynck J, Ceulemans R (2008) Bidirectional ammonia exchange above a mixed coniferous forest. Environ Pollut 154:424438. doi:10.1016/j.envpol.2007.11.030

Neirynck J, Kowalski AS, Carrara A, Ceulemans R (2005) Driving forces for ammonia fluxes over mixed forest subjected to high deposition loads. Atmos Environ 39:5013-5024. doi:10.1016/j.atmosenv.2005.05.027

Nemitz E, Sutton MA, Gut A, José RS, Husted S, Schjoerring JK (2000a) Sources and sinks of ammonia within an oilseed rape canopy. Agric For Meteorol 105:385-404. doi:10.1016/S0168-1923(00)00205-7

Nemitz E, Sutton MA, Schjoerring JK, Husted S, Wyers GP (2000b) Resistance modelling of ammonia exchange over oilseed rape Eiko Nemitz. Agric For Meteorol 105:405-425. doi:10.1016/ S0168-1923(00)00206-9

Nie W, Wang T, Gao X, Pathak RK, Wang X, Gao R, Zhang Q, Yang L, Wang W (2010) Comparison among filter-based, impactor-based and continuous techniques for measuring atmospheric fine sulfate and nitrate. Atmos Environ 44:43964403. doi:10.1016/j.atmosenv.2010.07.047

Rennenberg H, Kreutzer K, Papen H, Weber P (1998) Consequences of high loads of nitrogen for spruce (Picea abies) and beech (Fagus sylvatica) forests. New Phytol 139:71-86. doi:10.1046/j.1469-8137.1998.00181.x

Schjoerring JK, Mattsson M (2001) Quantification of ammonia exchange between agricultural cropland and the atmosphere: measurements over two complete growth cycles of oilseed rape, wheat, barley and pea. Plant Soil 228:105-115. doi:10.1023/A:1004851001342

Schjoerring JK, Husted S, Mattsson M (1998) Physiological parameters controlling plant-atmosphere ammonia exchange. Atmos Environ 32:491-498. doi:10.1016/S1352-2310(97)00006-X
Schrader F, Brummer C, Flechard CR, Kruit RJW, van Zanten MC, Zoll U, Hensen A, Erisman JW (2016) Non-stomatal exchange in ammonia dry deposition models: comparison of two state-of-the-art approaches. Atmos Chem Phys 16:1341713430. doi:10.5194/acp-16-13417-2016

Stamenkovic LJ, Antanasijevic DZ, Ristic MD, Peric-Grujic AA, Pocajt VV (2015) Modeling of ammonia emission in the USA and EU countries using an artificial neural network approach. Environ Sci Pollut R 22:18849-18858. doi:10.1007/s11356-015-5075-5

Sutton MA, Gut A, San José R, Husted S, Schjoerring JK (2001) Biosphere-atmosphere interactions of ammonia with grasslands: experimental strategy and results from a new European initiative. Plant Soil 228:131-145. doi:10.1023/a:1004822100016

Sutton MA, Erisman JW, Dentener F, Moller D (2008) Ammonia in the environment: from ancient times to the present. Environ Pollut 156: 583-604. doi:10.1016/j.envpol.2008.03.013

Wang Y (2012) Characteristics of stand structure and hydrological function of damaged Masson pine forests in the acid rain region of Chongqing. Dissertation, Chinese Academy of Forest, Beijing

Wang L, Schjoerring JK (2012) Seasonal variation in nitrogen pools and ${ }^{15} \mathrm{~N} /{ }^{13} \mathrm{C}$ natural abundances in different tissues of grassland plants. Biogeosciences 9:1583-1595. doi:10.5194/bg-9-1583-2012

Wang Y, Solberg S, Yu P, Myking T, Vogt RD, Du S (2007) Assessments of tree crown condition of two Masson pine forests in the acid rain region in South China. For Ecol Manag 242:530-540. doi:10.1016/j.foreco.2007.01.065

Wang L, Xu Y, Schjoerring JK (2011) Seasonal variation in ammonia compensation point and nitrogen pools in beech leaves (Fagus sylvatica). Plant Soil 343:51-66. doi:10.1007/s11104-010-0693-7

Wang L, Ibrom A, Korhonen JFJ, Arnoud Frumau KF, Wu J, Pihlatie M, Schjoerring JK (2013) Interactions between leaf nitrogen status and longevity in relation to $\mathrm{N}$ cycling in three contrasting European forest canopies. Biogeosciences 10:9991011. doi:10.5194/bg-10-999-2013

WRB (2006) World reference base for soil resources. FAO, Rome, 3 b. pp

Zhang X (2013) Photosynthetic Physiology for Pinus massoniana in Jinyun Mountain. Dissertation, Beijing Forestry University, Beijing

Zhang L, Wright LP, Asman WAH (2010) Bi-directional air-surface exchange of atmospheric ammonia: a review of measurements and a development of a big-leaf model for applications in regional-scale air-quality models. J Geophys Res-Atmos 115:D20310. doi:10.1029/2009jd013589

Zhu J, Mulder J, Solheimslid SO, Dörsch P (2013) Functional traits of denitrification in a subtropical forest catchment in China with high atmogenic N deposition. Soil Biol Biochem 57:577-586. doi:10. 1016/j.soilbio.2012.09.017

Zou Q (2000) Plant Physiology Experiment Instruction. China Agriculture Press (in Chinese), Beijing 